\title{
Plan Ceibal 2020: future scenarios for technology and education - the case of the Uruguayan public education system
}

\author{
Matías Mateu ${ }^{1 *}$, Cristóbal Cobo $^{2}$ and John Moravec $^{3}$
}

\begin{abstract}
In the present work, a set of future studies were implemented in order to answer the following question: What will the future scenarios be within the next 5 years regarding new technologies in the public education sector in Uruguay? For this purpose, two panels (consisting of 20 participants internal to the programme and 25 international experts external to the programme) were set up to conduct a Delphi study. In addition, a historical analysis of the use of Internet resources at schools (traffic and users connected to the network) was developed. This section of the study brought us the following findings: Primary and middle public school centres have experienced an exponential growth in Internet use as measured by traffic downloads and uploads, as well as by connections. Traffic doubled every 1 . 5 years, and connections had doubled roughly every year in the period from 2011 to 2015.

The study integrated the Delphi results and the analysis of Internet use as a method for prospective scenario planning, based on which four main possible educational and technological scenarios for 2020 were identified. This approach allowed us to define the possible technological future for the national education and technology policy.

We found that the key challenges were not technological, but social and cultural factors. Some of the challenges to be explored are (1) How can we understand the role(s) of teachers better?, (2) can we rethink how technology is being used, adopted and adapted in learning environments?, and (3) what systemic changes are needed to respond these possible scenarios better through policy development? The findings suggest that problems and challenges presented by new technological innovations in education are not solved by more technology.

Finally, we consider an approach such as this could work as a framework to help develop public education and technology policies in other countries with middle to high incomes that have strong orientations toward public education, including much of Europe.
\end{abstract}

Keywords: Education, Technology, Policy Delphi, Future scenarios, Plan Ceibal

\section{Introduction}

More than seven decades have passed since B. F. Skinner postulated his teaching machine to help children with their education through the paradigm of personalised, reinforced learning with programmed instructions [1]. Several decades after Skinner's disruptive idea, Pappert conceived the idea of one laptop per child for educational purposes in the 1960s [2]. However, it was not until the very beginning of the twenty-first century that the modern idea of one laptop per child arose. Fostered by the spread of the Internet and the constant decrease

\footnotetext{
* Correspondence: matmateu@gmail.com

'Plan Ceibal, Montevideo, Uruguay

Full list of author information is available at the end of the article
}

in the cost of devices, Nicholas Negroponte founded a non-profit organisation called One Laptop per Child in 2005. Only 1 year later, an entire country, Uruguay, was ready to test the entire paradigm via a public policy called Plan Ceibal.

\section{Plan Ceibal}

Plan Ceibal is a national educational policy in Uruguay that has the main objective of developing technological and educational innovations at system level in the public primary and secondary education system (ANEP). More than 700,000 students (ranging from five to 18 years of age), together with more than 40,000 teachers, are beneficiaries of Plan Ceibal. ${ }^{1}$ 
The process of Plan Ceibal can be described in three stages [3]. The first, from 2006 to 2009, had the main objective of decreasing the digital divide by granting access to devices and the Internet to students and teachers across the entire country [4]. The second stage was characterised by the integration of technological, educational and social support for the technological infrastructure [5]. The final stage, implemented since 2013, has been characterised by its focus on new educational practices [6].

In 2015, Plan Ceibal founded a study centre ${ }^{2}$ called Ceibal Foundation in order to conduct research and to cooperate with other research institutions in the field of technology and education worldwide. The study centre has allowed Plan Ceibal to begin a prospective research process in order to provide the policy with foresight concerning the trends and possible scenarios regarding new technologies in education and the deployment challenges thereof in a systematic manner. One of the results of this process is documented hereafter.

\section{Rethinking K-12 education for the twenty-first century}

Today, there is a great debate about emerging paradigms related to new practices and metrics in the educational field. For researchers and practitioners, there seems to be some difficulty when attempting to achieve a consensus concerning the important questions to be asked. For instance, as international evidence indicates, there is not a clear correlation between the access or the use of digital tools and the improvement in student performances [7, 8]. International studies show that standardised tests are not indicating major changes when measuring traditional performances. However, an alternative form of reading these results is that the measurement of socio-emotional changes in the learning, self-motivation, self-regulation among other capacities are very rarely measured or considered in these types of studies. It is considered necessary to think more about measuring what is valued instead of valuing that which is measured [9].

\section{New pedagogies for deep learning and Plan Ceibal}

One concrete attempt to address the problem of rethinking pedagogies for twenty-first century is Plan Ceibal's partnership with the Global Network for Deep Learning or NPDL (New Pedagogies for Deep Learning). This is an international initiative integrated by several countries. ${ }^{3}$ Uruguay is the only developing enation involved in the network. Deep learning is a conceptual and pedagogical framework where, "students develop competencies and capacities that prepare them to be creative, be connected, be capable of solving problems in a collaborative way as well as being holistic and good citizens contributing to the common well and also creating it" [10].

\section{Presentation of the research problem}

The general problem addressed in this research is the future of education in the Uruguayan context. More explicitly, how do we rethink educational systems and educational processes in the era of knowledge and accelerated cultural and technological changes? This work explores the subsequent questions: What possible scenarios could emerge in the next 5 to 10 years regarding technology enhanced education? How do we introduce future perspectives and studies in Plan Ceibal policy (and implementation)? More specifically, how do we apply future studies to the adoption of new technologies and to meet the challenges of effective integration into the educational process?

The purpose of this study was to provide a methodological approach and results that could help policy makers to be better prepared to answer these questions. In addition, this could provide an insight into a methodological framework to be used by other countries, particularly those in Europe that have a tradition of strong public education systems and policies.

\section{Objective and research questions}

In this study, a collection of future research techniques were implemented in order to construct future scenarios for the next 5 years with regard to new technologies in the public education sector in Uruguay.

This general objective was divided into three specific objectives:

- Objective 1: To analyse the evolution of Plan Ceibal's educational network (traffic and connections) for the period 2011-2015 and to project its evolution for the period 2016-2019

- Objective 2: To implement a Delphi study to obtain a ranking of the most relevant new technologies in the educational field for the period 2016-2020, as well as a set of most important challenges associated with the implementation of these new technologies

- Objective 3: To integrate objectives 1 and 2 via the use of scenario planning techniques in order to construct possible scenarios for the technological and educational levels of adoption in the case of the Uruguayan public education system.

The research questions formulated in order to achieve these goals were:

1. What has been the "aggregated use" 4 of teachers and students in the classroom in terms of Internet traffic and connections?

2. Which new technologies ${ }^{5}$ should Plan Ceibal leverage within the next 5 years and what are the key challenges ${ }^{6}$ associated with these technologies? 
3. What scenarios can we build by means of Plan Ceibal's educational technology supply and the educational system's demand for the period 20162019 ?

\section{Methodology}

\section{Methodological scheme}

In order to accomplish our goals, as well as to answer the proposed questions, the research was designed according to three phases, as presented in the methodological scheme in Fig. 1.

The three phases of the study are then described from a methodological point of view.

\section{Delphi study}

A classical definition of the Delphi method was given by Linstone and Turoff [11] as follows:

Definition 1 Delphi Method Must be characterised as a method to give structure to the communication process of a group. This method will allow the group to manage a complex problem effectively.

The reviewed literature states that Delphi is a method that is used to study mid- and long-term futures, although it does not help to predict future events. Instead, it helps experts in a specific field to achieve consensus concerning a specific topic $[12,13]$.

In general terms, the Delphi method is an iterative process, which normally has two to three rounds consisting of a series of questionnaires that are presented for consideration to the panellists; the questionnaires are then adjusted based on the panellists' answers and presented for reconsideration. Between the rounds, the panellists receive feedback regarding their answers, as well as feedback from the rest of the panel. In this sense, it is a qualitative, normative and exploratory method characterised by being anonymous and controlled debate and is based on the statistics derived from the answers of the group [12].

This method has been used extensively in the education field in recent decades [14], as well as in medical science and other fields $[15,16]$. Examples in the education sector are the K-12 Horizon Project ${ }^{7}$ from New Media Consortium [17, 18], the doctoral thesis by John Moravec [19] and the doctoral thesis by Somerville [20].

\section{Selection of the Delphi method}

After analysing different techniques used in future studies, the Delphi method was chosen given an intention to gather an important group of experts and asked them to express opinions about and to discuss the proposed topics. We used the K-12 Horizon Project [17] to generate the initial list of new technologies and the challenges to the implementation thereof.

\section{Panels}

Two panels were introduced, one consisting of international experts from outside of Plan Ceibal (external panel) and the other consisting of experts from within Plan Ceibal (internal panel).

External panel A preliminary list of 45 invited participants was prepared, based on the criterion that they would variously represent each of the four following categories: academia, education, industry and the government. A personalised invitation was sent to each invitee. The ages of participants ranged from 30 to 75 years, with an average of 50 years. Eight panellists came from the academic world, seven from the academic and industrial sectors at the same

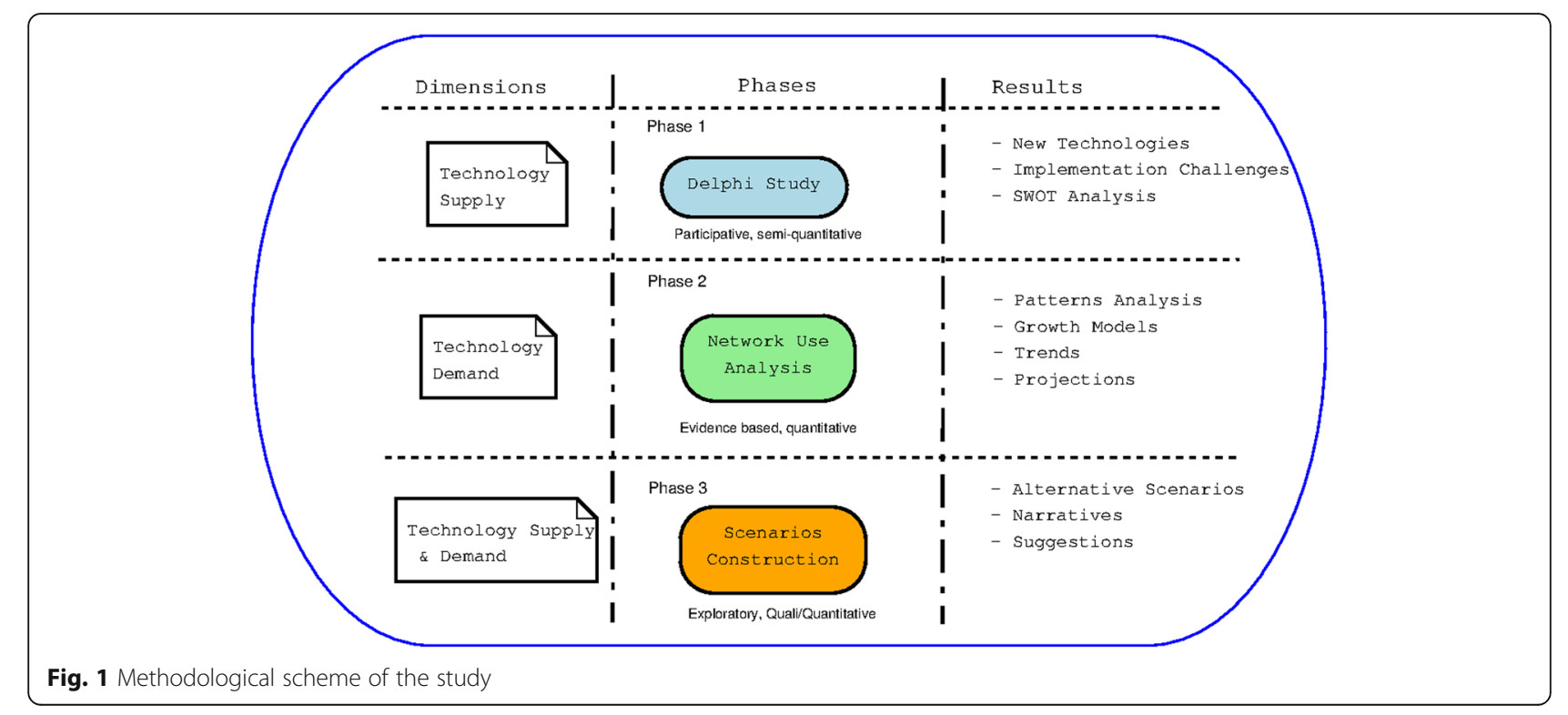


time, four from education and two from industry. Nine of the 21 had degrees in teaching. Finally, five were women and 16 were men. The members of the external panel are presented in Table 1.

Internal panel The internal panel was composed of 18 people (invited personally by the primary investigator), who were section chiefs, managers, directors and advisers from Plan Ceibal. Ten women and eight men participated. The main criterion for invitation was that they would represent both education and technology divisions in the organisation. Also, eight internal panellists had an education background, eight had an engineering background and two had an economy background. The average age of the panellists was 44 .

Questionnaires As mentioned previously, the Delphi process consisted of two rounds, which were answered by both panels and comprised of online surveys. Each survey was reviewed and tested prior to its application.

The main objective of the Delphi rounds was twofold:

1. To prioritise new technologies by considering the importance of adoption and the feasibility thereof

Table 1 External panel

Alejandro Maiche (FPSIC-UDELAR, Uruguay)
John Moravec (Education Futures, USA)
Ana Rivoir (FSC-UDELAR, Uruguay)
Laura Motta (ANEP, Uruguay)
Antonio M. Battro (indep., Argentina)
Leticia Britos (Stanford U., USA)
Carlos Petrella (FING-UDELAR, Uruguay)
Luis Garibaldi (CFE-ANEP, Uruguay)
Celsa Puente (CES-ANEP, Uruguay)
Luis Osin (GET, Israel)
Claudio Rama (inclep., Uruguay)
Marcelo Bagnulo (UCRMJETF, Spain)
Cristobal Cobo (Oxford U., UK)
Pablo Brenner (Collokia, Uruguay)
Daniel Kofman (Telecom ParisTech, France)
Pablo Sprechmann (NYU, USA)
Eugenio Severin (indep., Chile)
Rafael Mandressi (CNRS, France)
Fernando da Rosa (Ibirapita, Uruguay)
Raquel Aguilar (CTEP, Uruguay)
Fernando Santamara (U. de la Sabana, Colombia)
Gonzalo Mateos (Rochester U., USA)
Guillermo Spiller (Facebook, USA)

Alejandro Maiche (FPSIC-UDELAR, Uruguay)

John Moravec (Education Futures, USA)

Ana Rivoir (FSC-UDELAR, Uruguay)

Laura Motta (ANEP, Uruguay)

Leticia Britos (Stanford U., USA)

Carlos Petrella (FING-UDELAR, Uruguay)

Luis Garibaldi (CFE-ANEP, Uruguay)

Celsa Puente (CES-ANEP, Uruguay)

Luis Osin (GET, Israel)

Claudio Rama (inclep., Uruguay)

Cristobal Cobo (Oxford U., UK)

Pablo Brenner (Collokia, Uruguay)

Daniel Kofman (Telecom ParisTech, France)

lo Sprechmann (NYU, USA)
2. To define strategies to counter challenges to the implementation of these technologies in the case of Plan Ceibal

\section{Network use analysis}

The Delphi study explores the possible future supply of technology. In this section, we adopt the users' perspective; in other words, we analyse the users' demands for technology. We aim to compute a proxy for the demand for Internet resources and the evolution thereof in classrooms for the next 5 years. We will now summarise the phase 2 of the study, as it is synthesised in [21].

The analysis includes the universe of urban schools in the primary and secondary education systems. This includes 1535 schools, each with its own wireless LAN covering each classroom. ${ }^{8}$

The variables tracked were:

- Download Internet traffic

- Upload Internet traffic

- Simultaneous connections

These variables were collected hourly each day, beginning in 2011, via a network monitoring system and were stored on a database maintained by Plan Ceibal. We took a sample of each variable at a busy hour ${ }^{9}$ to conduct our analysis. The data collected were completely anonymous by nature.

\section{Scenario planning}

As stated in [12], and given the fact that we cannot predict the future with precision, scenario planning allows us to understand plausible scenarios better. The main motivation is to explore possible futures and not to choose a favourite one.

We also consider that these kinds of tools allow us not only to analyse possible futures but also to work actively toward a preferred future. This constructive approach is the basis of lavenir from the French Prospective School [22].

There is a wide range of definitions of scenarios in the visited bibliography [23-25]. The definition adopted for our purpose is presented in [26]:

Definition 2 Scenario A scenario is a hypothetical sequence of events built with the purpose of focusing attention on causal processes and decision points.

We followed the three basic stages of scenario construction methods, namely the identification of critical dimensions and key factors (design), the construction of scenarios (analysis) and visualisation and narration (results).

\section{Dimensions}

The two dimensions for scenario construction were: 
1. Supply of educational technology: This dimension was represented by Plan Ceibal's portfolio of educational technologies in the educational system.

2. Demand for educational technology: This dimension represents the level of use and appropriation of the different assets and devices with which Plan Ceibal supplies the educational system.

In other words, the Delphi study outputs were used as a proxy for the future supply of educational technology for the next 4 years, whereas the analysis of the network use was used to project the future demand for educational technology by Plan Ceibal's users.

\section{Scenario construction}

By combining the sign of the growth of both dimensions under analysis, we obtained four possible scenarios, illustrated in Table 2.

\section{Validation of scenarios}

There is no unique way to validate scenarios. In this work, we adopted a practical approach, namely the acceptance of the scenarios' construction and visualisation on the part of the stakeholders (decision makers at Plan Ceibal and practitioners from primary and education). A series of focus groups (one with decision makers and one with practitioners) were developed within Plan Ceibal. The Futures Wheel method [27] was used in order to investigate further consequences of each scenario presented. This technique was perceived as very enlightening and encouraged profound discussion among participants through different scenarios, showing their potential and robustness for exploration.

\section{Analyses}

\section{Delphi study}

Two rounds were administered during this stage. The first round was carried out in July, 2015. The external panel harvested 21 experts' answers, and the internal one 19. The second round took place during October, 2015. Fourteen external panellists answered the second quiz, and 17 answers were obtained for the internal second round. The minimum number of expected answers was 10 per panel [28].

Table 2 Future scenarios based on supply of and demand for educational technology

\begin{tabular}{llll}
\hline Scenario & Demand & Supply & Paradigm \\
\hline $2020-1$ & + & + & New \\
$2020-2$ & + & - & Traditional \\
$2020-3$ & - & + & Conflict \\
$2020-4$ & - & - & No paradigm \\
\hline
\end{tabular}

\section{New technologies}

In order to process the responses, an interquartile range $(I Q R)$ and interquartile deviation (IQD) was computed for each item:

$$
\mathrm{IQD}=\mathrm{IQR} / 2(1)
$$

After the first round, each technology was ranked according to the average score and the degree of consensus was computed. The IQD indicated the dispersion of answers along a given scale and is used as a proxy for consensus measurement $[15,29]$. To calculate IQD, the IQR is first computed:

$$
\mathrm{IQR}=\text { Interquartile range }=\left|P_{75 \%}-P_{25 \%}\right| \text { (2) }
$$

The smaller the value of IQR is, the greater the consensus of the group concerning that item is [30]. With regard to a 5-point Likert-type scale, ${ }^{10}$ a dynamic range of authors uses 1.00 as the threshold of statistical consensus $[19,29]$.

To generate the ranking of new technologies, we ordered the items according to the highest and lowest average scores IQR.

\section{First round}

The initial 39 new technologies were ranked, and the top 20 were selected for the second round.

\section{Second round}

In the second round, three different dimensions were explored:

- Horizon of adoption: 2 to 4 years

- Impact on the learning process: scale 0 to $3 ; 0=$ no impact and $3=$ high impact

- Usability: scale (0)

For the components of impact and usability, a metric called relevance was generated, which establishes the importance of adoption. In addition, with the dimension of the horizon of adoption, they were sorted chronologically.

\section{Implementation challenges \\ First round}

Panellists were asked to rank five of the 19 initial items in terms of their importance. Given the selection frequency of each item and its order of importance for each panellist, a ranking was created. The top five implementation challenges were then analysed in the second round.

\section{Second round}

In the second round, two dimensions of the top five challenges were further evaluated by the panel:

- Implementation difficulty

- Forecast for the year 2020

Panellists were also asked to complete a field with a justification of the answers and a field with proposed 
strategies to leverage the resolution of each implementation challenge.

Based on implementation difficulty and the forecast for 2020 dimensions, a metric called feasibility was tabulated, which indicates the extent to which each implementation challenge could be solved by 2020 .

From the textual answers and by using content analysis techniques [31], two outcomes were obtained:

1. SWOT Analysis (strengths, weaknesses, opportunities and threats) to solve implementation challenges

2. Typology of strategies to boost the resolution of principal implementation challenges

\section{Network use analysis}

The network analysis focuses on patterns, cycles and seasonal effects, as shown in Fig. 2. We present two charts. The first, aggregated into quarters, shows a consistent increase in the traffic demand from quarter to quarter. In the second chart, the aggregation is by month, showing a dramatic decrease during the summer break (December to February) and a moderate decrease during the winter break (July).

Figure 3 illustrates the evolution of demand and the capacity of the Internet bandwidth in the period from
2011 to 2015. The demand has increased about four times in the last 2 years of the study, whereas the capacity almost doubled in the same period. The relationship between the demand for the network (traffic and connections) and the demand for infrastructure is included in the analysis. This information illustrates the requirements that the network supplier (Plan Ceibal) has to consider when planning the evolution of the demand.

Finally, Fig. 4 shows a projection of the trend for the next years. This considers that the behaviour of the global users remains the same.

\section{Scenario construction}

Each of the four scenarios shows a possible paradigm regarding the adoption and use of technologies in the public education system in Uruguay. The word paradigm is used to refer to a dominant educational and technological model in the system under study.

When analysing each scenario, we identified key characteristics:

- 2020-1: Transformational ${ }^{11}$ scenario. A new equilibrium is achieved between supply and demand via the powerful use and effective adoption of technology in the field of education.
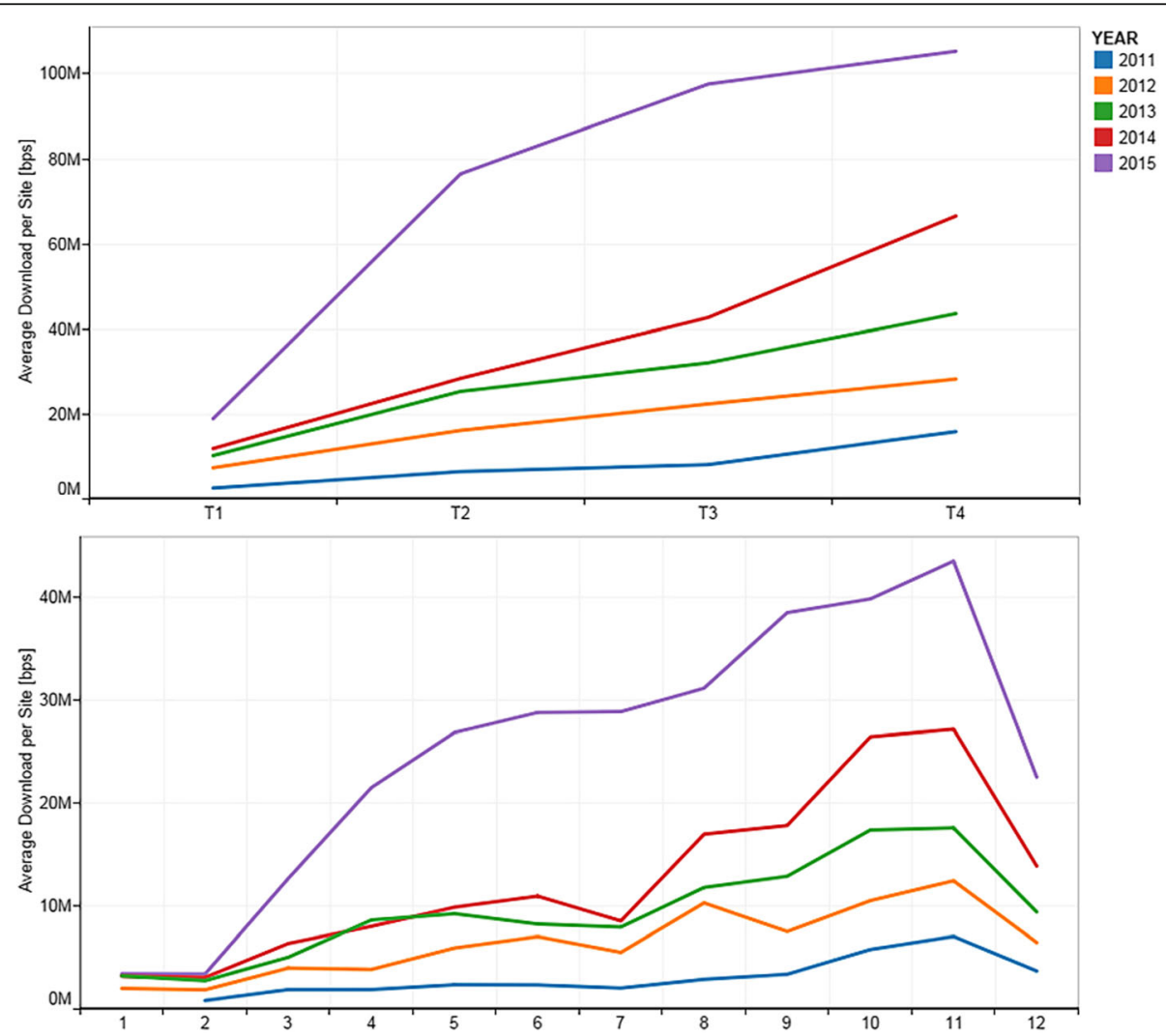

Fig. 2 Global Internet traffic download at schools 


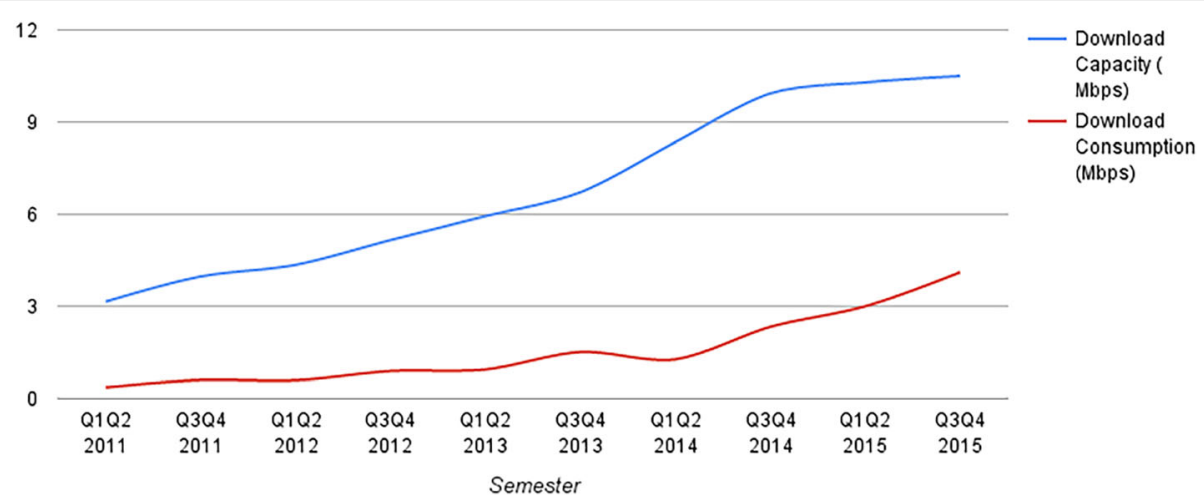

Fig. 3 Bandwidth capacity versus consumption of Internet at schools

- 2020-2: The supply is drastically reduced by political and economic considerations. The system tends to go back to previous stages before the existence of Plan Ceibal.

- 2020-3: A conflictive scenario in which Plan Ceibal and the educational system struggle to take the dominant paradigm in the field of technology and education.

- 2020-4: Collapsing scenario, in which the system descends to a "lower" stage of development (as Dator discussed [32]) and is about to become extinct. However, this should not necessarily be seen as a worst-case scenario.
In the "Results" section, a map is presented to visualise the four scenarios, as well as narration based on key factors.

\section{Limitations of the study}

In the Delphi study, there were three main limitations. The first was that the number of iterations was limited to two rounds in order to fit into the time-frame of the project. Secondly, the tools to support communications and quizzes did not allow for the fluency of interaction with and real-time feedback to the panellists. Finally, new items suggested the panels could not be incorporated into the initial questionnaire.

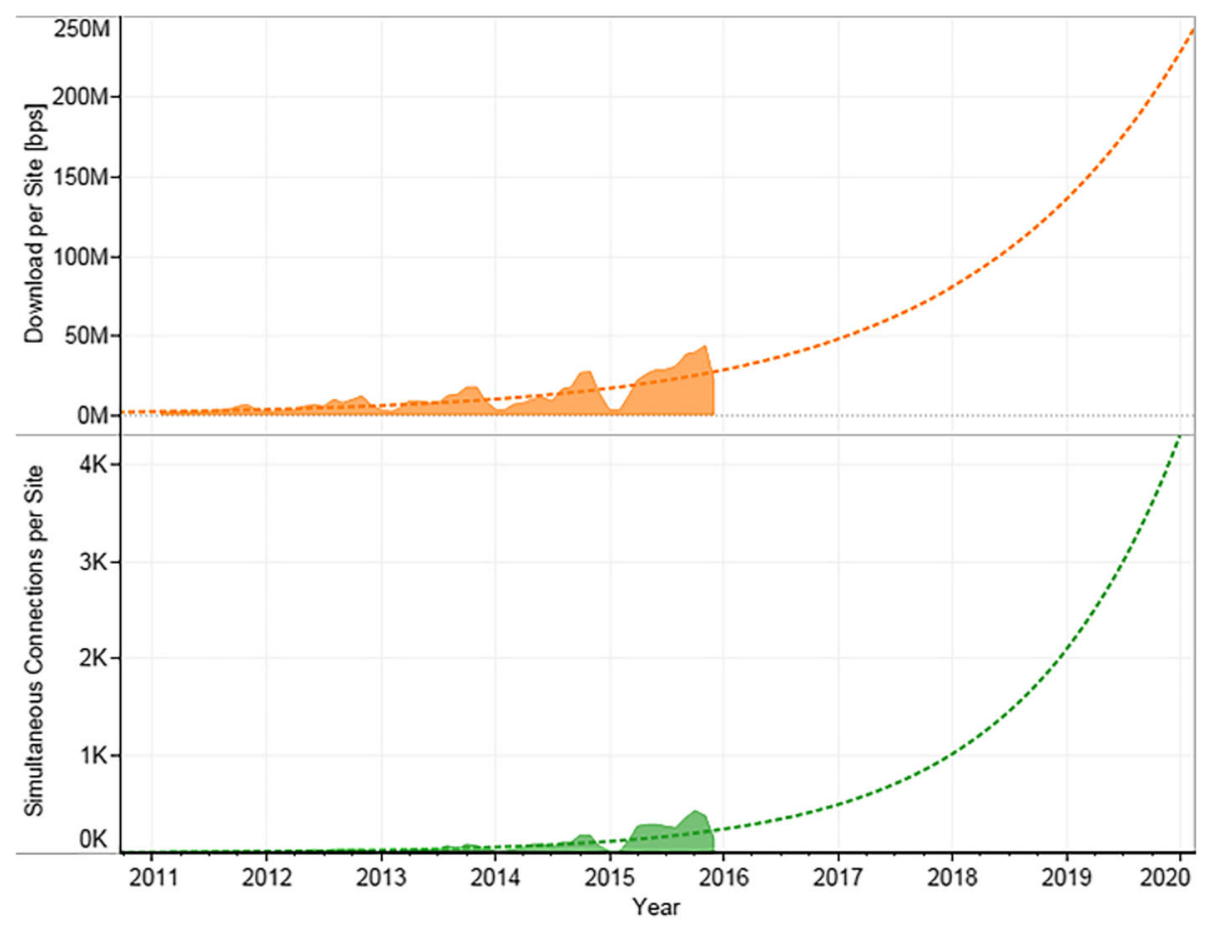

Fig. 4 Schools' Internet traffic growth projection 
With regard to the network use analysis, two main limitations appeared. The first is it was not possible to identify whether the traffic and connections come from devices delivered by Plan Ceibal or from personal devices. Secondly, it was not possible to distinguish the nature of the traffic (in other words, whether it was educational, recreational or another kind of activity on the network.)

Another limitation of the study was the time scope: 5 years. We consider it was an appropriate time frame because it matches strategic time scope. A long-term scenario (10-20 years or more) would have brought more complexity to the analysis taking into account uncertain political and cultural dimensions among others.

Finally, with regard to the scenario planning, as explained earlier, it is important to stress that its goal is not to predict but to identify, elucidate, align and understand relevant trends that are influencing the actors and the contexts that are linked to education and technology.

\section{Results and Discussion}

A principal result of the research is that challenges to achieving transformative and desirable scenarios for technological and educational integration at the system level are not of a technological nature. This finding is supported by the evidence driven directly from answers both in internal and external panels. Nine out of 10 top challenges prioritised by Delphi panels refer to the education process mainly, not to the technological one (see Table 4). This is a major confirmation of Plan Ceibal's Public Policy and focus on new pedagogies accelerated by new technologies (and not the other way around).

\section{Delphi outcomes}

\section{New technologies ranking}

The first output from the Delphi rounds is the ranking of most relevant new technologies for each panel. This can be seen in Table 3 .

\section{Ranking of implementation challenges}

The second output of the Delphi study is the ranking of the challenges. In Table 4, we summarise the top five implementation challenges based on both panels' views. A high level of overlap was found between internal and external rankings.

\section{Network use analysis}

The most important finding is the exponential nature of the growth of Plan Ceibal's Internet traffic at an aggregate level (i.e. the entire education system). Download traffic has grown 13 times between 2011 and 2015. CISCO VNI [33] reported that global Internet download traffic had grown five times in the same period. In other words, Plan Ceibal's Internet
Table 3 New technologies ranking sorted by relevance

\begin{tabular}{lll}
\hline Rank & External panel & Internal panel \\
\hline 1 & Cloud Computing & Adaptive Learning \\
2 & On-line Learning & Mobile Learning \\
3 & Social Networks & On-line Learning \\
4 & Mobile Broadband & Social Networks \\
5 & Mobile Learning & Virtual Remote Labs \\
6 & Info Visualisation & Gamification \\
7 & Adaptive Learning & Mobile Broadband \\
8 & Gamification & Learning Analytics \\
9 & Bring your own Device & Bring your own Device \\
10 & Learning Analytics & Cloud Computing \\
11 & On-line identity & Inverted Classroom \\
12 & Crowd-sourcing & Badges \& Micro-credits \\
13 & Flipped Classroom & MOOCs \\
14 & Visual Data Analysis & Open Licensing \\
15 & New Generation Batteries & Augmented Reality \\
16 & Augmented Reality & Speech-text Translation \\
17 & Open Hardware & Holography \\
18 & Internet of Things & Internet of Things \\
19 & Natural User Interfaces & Crowd-sourcing \\
20 & Semantic Applications & Self-quantified \\
\hline
\end{tabular}

use has grown about 2.5 times faster than that of global Internet users.

Download traffic doubled every 18 months during the period between 2011 and 2015 (an average annual growth rate of $68 \%$.

With regard to simultaneous connections per site, we found that this index doubled every 12 months between 2011 and 2015 (an average annual growth rate of $105 \%)$.

Another finding was related to the download/upload ratio, which was 11 to 1 , on average, between 2011 and 2015. That means that, for every 11 bits of information that users consume, 1 bit of information is delivered from a user's device to the network.

\begin{tabular}{lll}
\multicolumn{2}{l}{ Table $\mathbf{4}$ Top 5 implementation challenges } \\
\hline Rank & External & Internal \\
\hline 1 & $\begin{array}{l}\text { Profit from system-wide } \\
\text { big data }\end{array}$ & $\begin{array}{l}\text { Integrate new techs in the } \\
\text { educational change process }\end{array}$ \\
2 & $\begin{array}{l}\text { Integrate new techs in the } \\
\text { educational change process }\end{array}$ & $\begin{array}{l}\text { Empower teachers on their } \\
\text { educational practices }\end{array}$ \\
3 & $\begin{array}{l}\text { Empower teachers on their } \\
\text { educational practices }\end{array}$ & $\begin{array}{l}\text { Integrate personalised learning } \\
\text { Rethink teachers' and } \\
\text { professors' roles } \\
\text { Integrate personalised learning }\end{array}$ \\
& $\begin{array}{l}\text { Develop complex thinking } \\
\text { and communications } \\
\text { Rethink teachers' and } \\
\text { professors' roles }\end{array}$ \\
\hline
\end{tabular}


A final parameter that is very important in the planning and roadmapping of the educational infrastructure is the ratio between the download bandwidth demand and the installed capacity (supply). This ratio was reported as being $40 \%$ utilisation of installed capacity.

All these findings confirm the exponential growth of both traffic and connections in Plan Ceibal's network in the period from 2011 to 2015 .

\section{Scenario planning}

The four scenarios are illustrated in Fig. 5. The following is a description of the four scenarios constructed.

\section{0-1: new paradigm}

This scenario presents a new paradigm that is based on systemic innovation of educational technologies, with a key role being played by the association Plan Ceibal ANEP.

The most relevant characteristic of this scenario is that the main challenges have been resolved, whereas the design and implementation have been consolidated into a new methodological framework for the system-or New Pedagogies for Deep Learning. This new paradigm implements, tests and improves disruptive pedagogical practices and experiments with a focus on methodology (schools' networks), pedagogy (based on creativity, problem-solving and collaboration) and assessment (using with new metrics for assessing educational outputs) [34].

From an educational change perspective, the system fosters techno-educational innovations, and changemanagement capacities are developed within the system.
Plan Ceibal consolidates its philosophy of "learning by doing", and improvements are made in the process of the personalisation of education based on analytics and future studies, among other methodological approaches to making decisions concerning the public policy.

\section{0-2: traditional paradigm}

This scenario drastically reduces Plan Ceibal's scope by either institutional or economic restrictions. The public policy is discouraged.

The education system has experimented with a regression in its capacity to develop techno-educational innovations. Neither the equity nor the quality of Plan Ceibal has been fulfilled. From the point of view of educational change, the education system loses its capacity to develop techno-educational innovations at the system level, and there is no development of change management capacity either.

Plan Ceibal is reduced to its minimum expression, and a new divide in access and use of educational technologies is increasing.

\section{0-3: conflict paradigm}

This is a scenario in which two paradigms face each other, namely the traditional and the emerging paradigms proposed by Plan Ceibal. As the system has a series of stakeholders who interact with each other, this complexity introduces a divergence of perspectives among public, private and communitarian visions regarding education.

The rivalry among stakeholders and parts of the system neutralise the impacts and effects of the technoeducational innovations developed by Plan Ceibal.

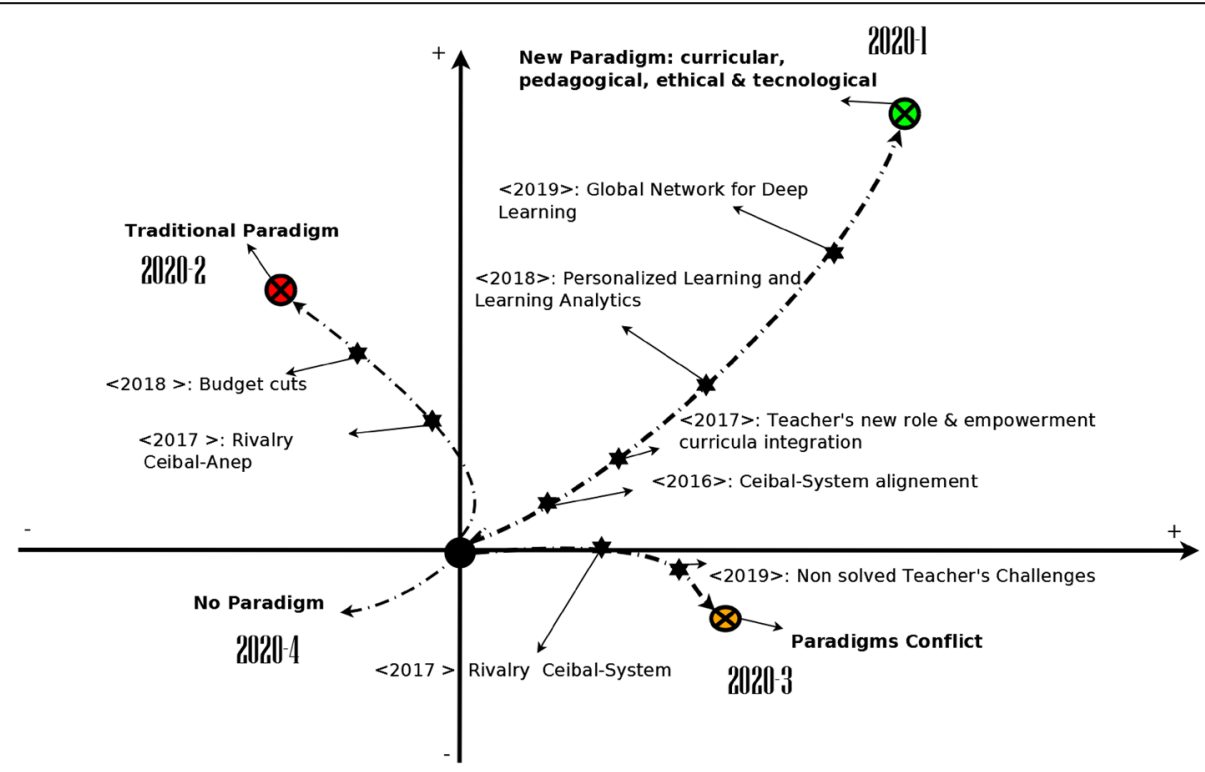

Fig. 5 Future scenarios for technology and education ( $x$-technology supply, $y$-technology demand) 


\section{0-4: collapse paradigm}

In this scenario, the system itself is redefined. It is the end of the system as we currently know. The system descends to a "lower" stage of development and could also become extinct. This should not necessarily be seen as a worst-case scenario. This could be given by a radical discontinuity public policy (given by a new administration, for instance). The system is about to be redefined; thus, innovation capabilities and culture depend on the redefinition of the same system.

\section{Conclusions}

As we have seen, the Delphi method allowed us to map the relevance of new technologies toward the year 2020 and to identify critical challenges for effective adoption of these new technologies in public education. In addition, a great degree of similarity was seen between the internal and external panels.

The network use analysis then modelled the users' demands for technology and evidenced that the beneficiaries of Plan Ceibal have profited from resources at an exponentially accelerated rate.

The third objective was to create possible scenarios for technological and educational integration. We found four plausible scenarios concerning the demand for and the supply of technology.

The two dimensions used to build these scenarios were technological supply (measured through the Delphi study output) and technological demand (measured through the patterns of network use). The key factors that would determine each scenario were constructed from critical challenges identified in the Delphi study.

Many aspects still remain open for further studies. One aspect is how to harmonise the long and short-term effects of technology.

As a public policy, Plan Ceibal has a five-year budget and maintains a strategic view for action in this time frame. On the other hand, we tend to overestimate the short-term effects of technology while underestimating the long-term effects (Amara's law ${ }^{12}$ ).

For governments and administrations that typically manage budgets for no more than 4 to 5 years, a prospective long-term view of the technological and educational integration problem becomes a great challenge.

Furthermore, challenges for public policy do not exist solely within the complexity of our system studied but also with regard to the change of complexity in technological, educational and political dimensions over time.

This study tries to bridge the gap between strategic short-term decisions in technological public policy and implementation (5 years) and a long-term, comprehensive perspective effective integration of education with technologies (20 to 30 years). The next steps to continue this work is to systematise a prospective process based on expert panels, focus groups, or other techniques that enable the flow and organisation of opinions and views concerning possible technological and educational futures for Plan Ceibal. This may help anticipate and align public educational and technological policies and craft implementation strategies to help realise preferred futures.

Finally, the authors consider an approach like this could work as a framework to help public educational and technological policies in other countries with middle to high incomes that have strong public education policies worldwide, with a particular eye toward Europe. As Michel Godet said [22], "... the world changes but problems remain the same". Thus, this vision of the invariance of problems can give us a hint regarding that on which we need to focus; in this case, the purpose of educational change across the world.

\section{Endnotes}

${ }^{1}$ Information about Plan Ceibal can be found on its web-site: www.ceibal.edu.uy/en/institucional) [Last visited: 31st of July, 2017]

${ }^{2}$ http://www.fundacionceibal.edu.uy/en [Last visited: 31st of July, 2017]

${ }^{3}$ The seven participating countries are Australia, Canada, Finland, the Netherlands, New Zealand, the USA and Uruguay.

${ }^{4}$ Accounts for the sum of the traffic or connections of all users of the network at a given time.

${ }^{5}$ Set of educational technologies, access technology, methodologies and digital strategies. The definition was extracted from the K-12 Horizon Project 2014/ 2015 [17].

${ }^{6}$ Set of technological, pedagogical, curricular, political, ethical and institutional issues that could act as barriers to the adoption and integration of new technologies.

${ }^{7}$ https://www.nmc.org/nmc-horizon/ [Last visited: 31st of July, 2017].

${ }^{8}$ For a comprehensive understanding of Plan Ceibal's network architecture, please visit (Spanish) http://blogs. ceibal.edu.uy/tecnologia/redceibal/ [Last Visited: 27th of July, 2017].

${ }^{9} \mathrm{~A}$ busy hour is determined statistically and refers to the hour of the day during which the network registers the greatest use in terms of traffic and connected users. By selecting busy hour time frame, we observe the system's behaviour when it is statistically demanded the most, being able to compare it to its maximum capacity, for instance.

${ }^{10}$ https://en.wikipedia.org/wiki/Likert_scale [Last visited: 12th of May, 2017].

${ }^{11}$ Jim Dator explained future scenarios as being a combination of four paradigms: Transformation, Continued Growth, Discipline and Collapse [32]. 


\section{${ }^{12}$ https://en.wikipedia.org/wiki/Roy_Amara\#Amara. 27s_law [Last Visited: 1st of August, 2017].}

\section{Acknowledgements}

Special thanks are extended to all the participants of the panels and Jorge Rasner from Universidad de la República, Uruguay.. We also would like to thank all Plan Ceibal staff, particularly Sofía Doccetti and Fiorella Haim, for the support.

\section{About the authors}

Matías Mateu is a Telecommunication Engineer and Technical Manager at Plan Ceibal. He has co-led the implementation of the infrastructure and new technologies in the Uruguayan education system for the last 10 years. He is co-leading Plan Ceibal's strategy to develop big data analytics and the prospective process of \#edtech. His purpose is to help people and systems to embrace change and uncertainty through strategic and future-oriented mindsets. He holds a Master. in Innovation Management (2016), a Diploma in Telecommunication Engineering (2013) and a Degree in Electrical Engineering (2006), all from the Universidad de la República, Uruguay. Cristóbal Cobo (Ph.D.) is the Director of the Center for Research Ceibal Foundation in Uruguay and is also an associate researcher at the Oxford Internet Institute at the University of Oxford in the UK. He has served as an external evaluator for the Inter-American Development Bank, the National Science Foundation and MIT Press (US). Cobo works at the intersection of the future of education, knowledge, technology and heutagogy. John Moravec (Ph.D.) is the founder of Education Futures, a research and advisory firm with a service mission, serving governments, schools and universities in the Americas and Europe. His research and action scholarship agendas are focused on exploring the convergence of globalisation, innovation society, accelerating change in human knowledge development, and building positive futures for knowledge creation systems in an era of exponential uncertainty.

\section{Authors' contributions}

All authors read and approved the final manuscript.

\section{Competing interests}

The authors declare that they have no competing interests.

\section{Publisher's Note}

Springer Nature remains neutral with regard to jurisdictional claims in published maps and institutional affiliations.

\section{Author details}

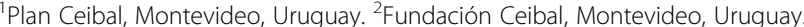
${ }^{3}$ Education Futures LLC, Minneapolis, MN, USA.

Received: 5 October 2017 Accepted: 11 April 2018

Published online: 21 May 2018

\section{References}

1. Skinner, B.F.: Review lecture: the technology of teaching. Proceedings of the Royal Society of London Series B, Biological Sciences 162(989), 427-443 (1965). URL http://www.jstor.org/stable/75554

2. Papert, S.: Teaching children thinking. In: Proceedings of IFIPS world congress on computer and education. Amsterdam, the Netherlands (1970)

3. Fullan M, Watson N, Anderson S (2013) Ceibal: Los próximos pasos. Michael Fullan Enterprises, Toronto, Canada

4. Plan Ceibal y ANEP (2009) En el camino de Plan Ceibal, Referencia para padres y educadores. UNESCO

5. Plan Ceibal y ANEP (2011) El modelo Ceibal. Nuevas tendencias de aprendizaje. Plan Ceibal and ANEP

6. Plan Ceibal y ANEP (2013) Aprendizaje abierto y Aprendizaje flexible: más allá de los formatos y espacios tradicionales. Plan Ceibal y ANEP

7. Busso M, Cristia J, Hincapié D, Messina J, Ripani L (eds) (2017) Aprender mejor. Políticas públicas para el desarrollo de habilidades. Banco Interamericano de Desarrollo Available at: https:/www.iadb.org/es/ habilidades

8. Chaia, A. Child, F, Dorn, E, Frank, M. Krawitz, M, \& Mourshed, M. (n.d). What drives student performance in Latin America? | McKinsey \& Company.
Retrieved February 21, 2018, from https://www.mckinsey.com/industries/ social-sector/our-insights/what-drives-student-performance-in-latin-america

9. Cobo C (2016) La innovación pendiente. Reflexiones (y Provocaciones) sobre Educación, Tecnología y Conocimiento. Penguin Random House Grupo Editorial Uruguay URL http://digital.fundacionceibal.edu.uy/jspui/ handle/123456789/159

10. Fullan M, Langworthy M (2013) Towards a new end: new pedagogies for deep learning. Tech. rep., Global Alliance For Deep Learning

11. Linstone H. A, \& Turoff M. (Eds) (1975). The delphi method. Reading, MA: Addison-Wesley. pp. 3-12.

12. Cobo C, Moravec J (2011) Aprendizaje Invisible. Hacia una nueva ecolog'ıa de la educación, chap.4. Herramientas y metodologías para estudiar el futuro de la educación. Collección Transmedia XXI. Laboratori de Mitjans Interactius/Publicacions i Edicions de la Universitat de Barcelona, Barcelona, España

13. Glenn, J., Gordon, T.: Futures research methodology: version 3.0. The millennium project (2009)

14. Green RA (2014) The delphi technique in educational research. SAGE Open 4(2). https://doi.org/10.1177/2158244014529773

15. Chipchase L, Schabrun S, Cohen L, Hodges P, Ridding M, Rothwell J, Taylor J, Ziemann U (2012) A checklist for assessing the methodological quality of studies using transcranial magnetic stimulation to study the motor system: an international consensus study. Clin Neurophysiol 123(9):1698-1704. https://doi.org/10.1016/j.clinph.2012.05.003

16. Doran DM, Baker GR, Szabo C, Mcshane J, Carryer J (2014) Identification of serious and reportable events in home care: a Delphi survey to develop consensus. Int J Qual Health Care 26(2):136-143. https://doi.org/10.1093/ intghc/mzu008 URL http://intghc.oxfordjournals.org/content/26/2/136

17. Johnson L, Adams Becker S, Estrada V, Freeman A (2014) NMC horizon report: 2014 k-12 education edition. The New Media Consortium, Austin

18. Johnson L, Adams Becker S, Gago D, Garcia E, Martn S (2013) Nmc perspectivas tecnológicas: Educación superior en America Latina 2013-2018, un análisis regional del informe horizon del nmc. Tech. rep. The New Media Consortium, Austin

19. Moravec J (2007) A new paradigm of knowledge production in Minnesota higher education: a Delphi study. Ph.D. thesis, University of Minnesota

20. Somerville JA (2007) Critical factors affecting the meaningful assessment of student learning outcomes: a Delphi study of the opinions of community college personnel. Ph.D. thesis, Oregon State University

21. Cobo C, Mateu M (2016) A conceptual framework for the analysis and visualization of Uruguayan inter- net for education. Interactions Magazine VOLUME XXIII 6:70-73. https://doi.org/10.1145/2998387 URL http://digital. fundacionceibal.edu.uy/jspui/handle/123456789/157

22. Godet M, Coates JF, Gerber A, Radford K (2006) Creating futures. Economica, Genve, Paris, London

23. Davis $G$ (2002) Scenarios as a tool for the $21^{\text {st }}$ Century. Shell Centre, London, England.

24. Meinert S. (2014), "Field Manual Scenario Building". Brussels: European Trade Union Institute.

25. Kosow H, Gaßner R (2008). Methods of future and scenario analysis: overview, assessment, and selection criteria. Bonn: Deutsches Institut für Entwicklungspolitik. URL http://www.die-gdi.de/en/studies/article/methodsof-future-and-scenario-analysis-overview-assessment-and-selection-criteria/

26. Kahn H, Wiener, A. J, \& Hudson Institute (1967). The year 2000: A framework for speculation on the next thirty-three years. New York: Macmillan.

27. Glenn J. C, Gordon T. J, \& Florescu E (2009). The Millennium Project. 2007 State of the Future.Washington: The Millennium Project. ISBN, 978(0): 9818941-2.

28. Hsu CC, Sandford BA (2007) Minimizing non-response in the Delphi process: how to respond to non-response. Practical Assessment, Research \& Evaluation 12(17):62-78

29. Raskin MS (1994) The Delphi study in field instruction revisited: expert consensus on issues and research priorities. J Soc Work Educ 30(1):75-89. https://doi.org/10.1080/10437797.1994.10672215

30. Rayens MK, Hahn EJ (2000) Building consensus using the policy Delphi method. Policy, Politics, \& Nursing Practice 1(4):308-315. https://doi.org/10 1177/152715440000100409 URL http://ppn.sagepub.com/cgi/doi/10.1177/ 152715440000100409

31. Krippendorff K, Wolfson L (1990) Metodología de análisis de contenido: teoría y práctica. Paidós Comunicación, Paidós 
32. Dator J.A, Sweeney J.A, Yee A.M (2015). Alternative Futures at the Mānoa School. In: Mutative Media. Lecture Notes in Social Networks. Cham: Springer.

33. CISCO (2015) Cisco visual networking index: global mobile data traffic forecast update, 20142019. Tech rep., CISCO

34. Cobo, C., Brovetto, C., Gago, F.: A global network for deep learning: the case of Uruguay. Digital inclusion: transforming education through technology (2016). URL https://digital.fundacionceibal.edu.uy/jspui/ handle/123456789/158

\section{Submit your manuscript to a SpringerOpen ${ }^{\circ}$ journal and benefit from:}

- Convenient online submission

- Rigorous peer review

- Open access: articles freely available online

- High visibility within the field

- Retaining the copyright to your article

Submit your next manuscript at $\boldsymbol{\sim}$ springeropen.com 